\title{
Sel Induk Mesenchymal Secretome untuk Gangguan Permukaan Okular
}

\author{
Mia Arifka ${ }^{1 *}$, Nasrul Wathoni ${ }^{1}$, Gofarana Wilar ${ }^{2}$ \\ ${ }^{1}$ Departemen Farmasetika dan Teknologi Farmasi, Fakultas Farmasi, Universitas Padjadjaran, \\ Jatinangor 45363, Indonesia. \\ ${ }^{2}$ Departemen Farmakologi, Fakultas Farmasi, Universitas Padjadjaran, Jatinangor 45363, Indonesia. \\ ${ }^{\star}$ E-mail: mia19005@mail.unpad.ac.id \\ (Submit 23/12/2021), Revisi 19/01/2022), Diterima 13/02/2022), Terbit 03/03/2022)
}

\begin{abstract}
Abstrak
Gangguan permukaan okular adalah sekelompok penyakit heterogen yang sangat umum dengan berbagai etiologi dan gejala serta merupakan faktor risiko dengan komplikasi serius pada mata. Obat-obatan saat ini termasuk obat tetes mata yang dijual bebas tidak mengobati gangguan permukaan okular atau telah dikaitkan dengan berbagai efek samping yang mengarah pada pengobatan alternatif menggunakan terapi sel induk. Sel induk mesenchymal (MSC) adalah sel induk multipoten yang berpartisipasi dalam perbaikan jaringan dan memiliki potensi imunomodulator yang cukup besar untuk mengatasi gangguan permukaan okular. MSC mensekresi secretome dengan aktivitas autokrin dan parakrin yang bekerja menghambatan fibrosis dan apoptosis, penekanan sistem kekebalan lokal, peningkatan angiogenesis, dan diferensiasi sel induk dengan melibatkan faktor-faktor terlarut seperti IL-10, TGF- $\beta 1$, IL6, TNF-a dan faktor pertumbuhan endotel vaskular (VEGF). Aplikasi MSC-secretome pada kornea tikus setelah cedera secara in vivo diketahui mencegah perkembangan neovaskularisasi kornea. Mekanisme immunomodulasi MSC-secretome dalam memediasi regulasi inflamasi, angiogenesis dan neovaskularisasi pada gangguan permukaan okular dibahas dalam ulasan ini.
\end{abstract}

Kata kunci: MSC paracrine signaling, ocular surface disorders, secretome immunomodulatory, secretome mesenchymal stem cells

\section{Pendahuluan}

Kornea adalah pelindung mata paling luar dan terdiri dari tiga lapisan dengan asal germinal yang berbeda: epitel berasal dari ektoderm superfisial dan stroma dan endotelium muncul dari sel krista neural (jaringan mesekim). Studi eksperimental telah menunjukkan bahwa berbagai sel induk hadir di masing-masing lapisan ini [1]. Gangguan permukaan okular atau ocular surface disease (OSD) terjadi ketika homeostasis yang diatur dengan ketat pada permukaan okular terganggu. OSD adalah sekelompok penyakit dengan berbagai etiologi dan gejala di mana peradangan memainkan peran kunci dalam patogenesis. OSD yang umum ditemui dan dikelola dalam praktek klinis termasuk penyakit mata kering, 
disfungsi kelenjar meibom, penyakit mata alergi, konjungtivitis sikatrik, luka bakar kimia dan termal, trauma, refraktif setelah operasi kornea dan komplikasi terkait lensa kontak $[2,3]$. Luka kornea yang tidak sembuh-sembuh merupakan penyebab penting hilangnya penglihatan pada penyakit permukaan okular [4].

Pengobatan konvensional luka kornea umumnya berupa pelumasan, antibiotik, dan perban lensa kontak. Pengembangan dan pengenalan pengobatan modern untuk gangguan okular merupakan tantangan dalam kedokteran oftamologi. Meskipun ada kemajuan besar dalam pengobatan penyakit kornea, penyembuhan luka pada penyakit atau kerusakan kornea yang parah masih tetap menjadi tantangan saat ini [5]. Dalam beberapa tahun terakhir dokter mata telah menempatkan fokus yang lebih besar pada terapi menggunakan sel induk (Stem Cell), karena kemampuan pembaruan dan regenerasi jaringan di tubuh, tidak terkecuali jaringan mata [4]. Studi terbaru menunjukkan efek menguntungkan dari terapi berbasis sel induk pada penyembuhan permukaan mata terutama menggunakan sel induk mesenchymal (MSC) [6-9].

MSC ditemukan di sebagian besar jaringan dewasa, termasuk kornea/ limbus [10], dan memainkan peran penting dalam perbaikan dan pemeliharaan jaringan [4]. Selama dekade terakhir, MSC telah semakin diselidiki untuk potensi terapeutik mereka dalam berbagai penyakit manusia karena sifat anti-inflamasi, imunosupresif dan regeneratifnya. Namun, sampai saat ini sel induk mesenchymalal belum menjadi agen terapi yang banyak digunakan karena tantangan keamanan, biaya tinggi dan kesulitan dalam menyediakan produksi jangka panjang. Mekanisme kunci yang mendukung efek imunomodulator MSC adalah produksi faktor parakrin termasuk faktor pertumbuhan, sitokin, kemokin, dan ekstraseluler vesikel (EV) yang disebut secretome [11]. Sebelumnya telah ditunjukkan bahwa secretome MSC kornea manusia mampu menghambat neovaskularisasi kornea [12], dan memodulasi makrofag ke arah antiangiogenik dan imunofenotipe antiinflamasi [10].

Efek antiinflamasi dan penyembuhan oleh secretome dari MSC baru-baru ini telah dibuktikan dalam model eksperimental penyakit permukaan mata [13]. MSC yang diturunkan dari sumsum tulang pada luka epitel kornea dan luka bakar alkali telah ditunjukkan secara in vitro dan in vivo [6,9,14]. Dalam pengaturan ini, MSC secretome dianggap meningkatkan penyembuhan luka kornea melalui berbagai mekanisme, termasuk penekanan sitokin inflamasi, serta peningkatan regulasi sitokin antiinflamasi dan neovaskularisasi. Sebuah studi menunjukkan MSC secretome mengurangi kerusakan inflamasi pada kornea yang dihasilkan oleh cedera kimia dan mekanis dengan mengktifkan sel untuk mengekspresikan protein antiinflamasi TNF- $\alpha$ stimulated protein 6 (TSG-6) [15,16]. Selain itu, penggunaan MSC secretome juga memberikan keuntungan yang cukup besar dibandingkan transplantasi sel termasuk pembuatan, penyimpanan, penanganan, masa simpan produk dan potensinya sebagai produk biologis yang siap pakai [17]. Oleh karena itu, baru-baru ini penggunaan secretome yang berasal dari MSC telah menarik perhatian untuk keuntungan potensial mereka termasuk aplikasi pada gangguan permukaan okular. 


\section{Metodologi}

Ulasan ini menggunakan literatur yang berasal dari Scopus, PubMed, dan Google Scholar dengan menggunakan kata kunci, "MSC paracrine signaling", "ocular surface disorders", "secretome immunomodulatory", "secretome mesenchymal stem cells". Literatur yang dipilih termasuk MSC secretome untuk penggunaan medis potensial terutama dalam menangani masalah gangguan permukaan okular. Diagram alir metodologi dapat dilihat sebagaimana yang ditunjukkan oleh Gambar 1

\section{GAMBAR \& TABEL}

\section{Garphical Abstrak}

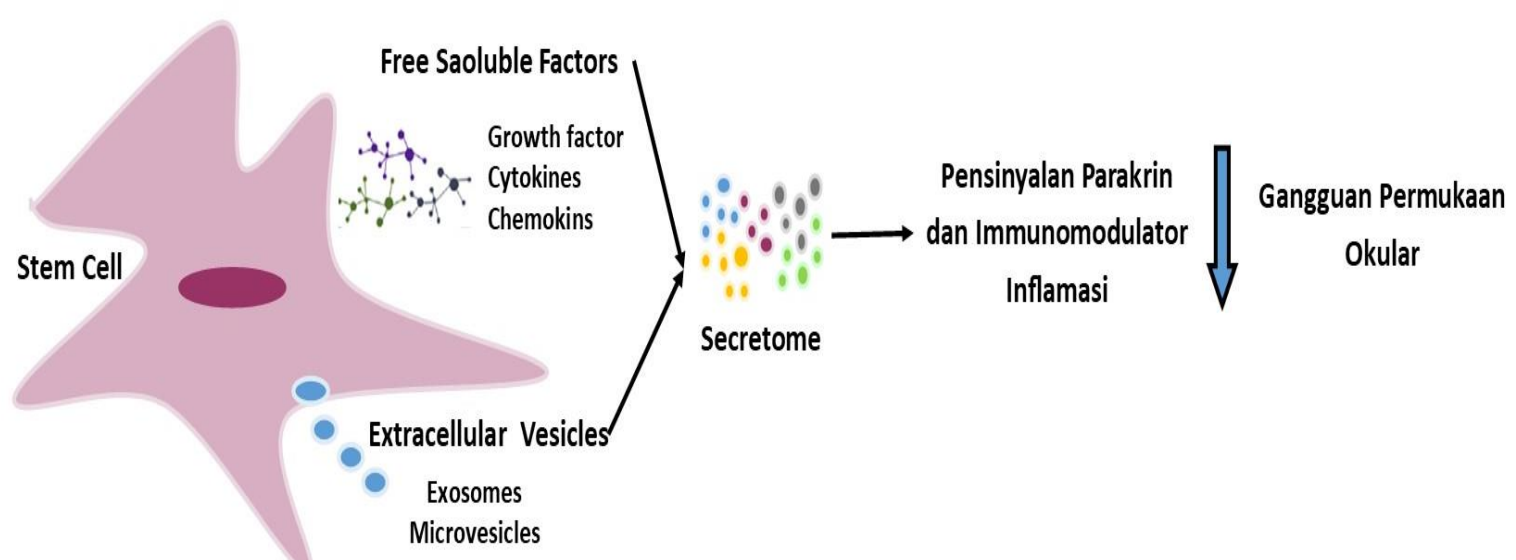

113 artikel dipilih untuk penyaringan awal

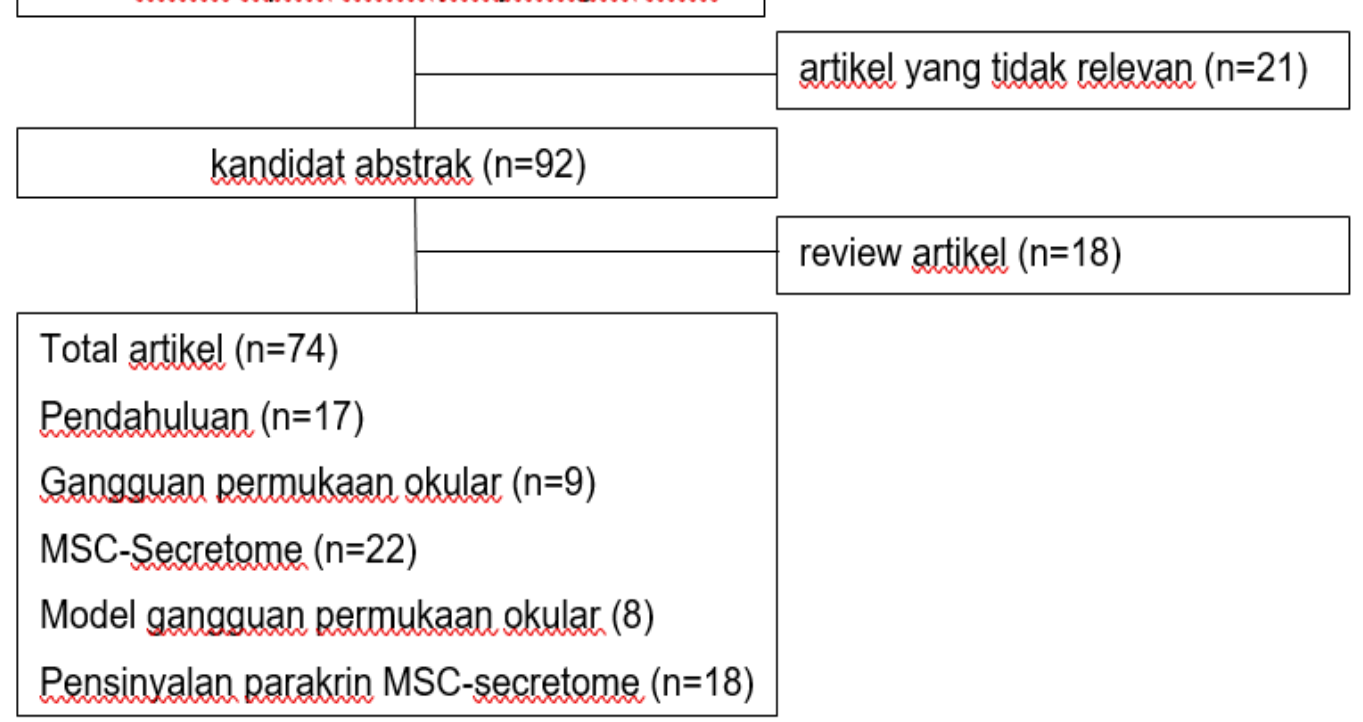

Gambar 1 Diagram alir metodologi yang digunakan dalam tinjauan ini. 


\section{Gangguan Permukaan Okular}

Permukaan okular terdiri dari kornea, konjungtiva, kelopak mata dan kelenjar lakrimal dan setiap gangguan dalam struktur ini dapat diklasifikasikan sebagai gangguan permukaan okular (OSD). Meskipun prevalensi OSD cukup tinggi, sayangnya, kasus sering tidak terdiagnosis atau tidak diobati karena kurangnya pemahaman tentang gejala, dan evaluasi yang tidak akurat. OSD mencakup kondisi seperti penyakit mata kering, disfungsi kelenjar meibom, penyakit alergi mata, luka bakar kimia dan termal, dan sebagainya. Penyakit permukaan mata dapat sangat mempengaruhi penglihatan dan kualitas hidup, dan dalam kasus yang parah dapat menyebabkan kebutaan. Untuk penyakit mata kering tidak ada studi berbasis populasi di Asia Selatan. Ada beberapa laporan berbasis rumah sakit yang diterbitkan, tetapi prevalensinya cukup bervariasi. Hal ini mungkin karena perbedaan lokasi geografis serta kurangnya kuesioner standar dan tes objektif untuk mengkonfirmasi diagnosis mata kering [18]. Dalam studi epidemiologi yang dilakukan secara global, prevalensi penyakit mata kering adalah sekitar $5 \%$ hingga $50 \%$, dan cukup tinggi pada penduduk lanjut usia, yaitu sekitar 14$33 \%$. Diketahui bahwa bertambahnya usia merupakan salah satu faktor risiko penyakit mata kering, jadi dengan populasi yang menua, kita cenderung melihat lebih banyak penyakit mata kering di Asia Selatan [19,20].

Konjungtivitis alergi mewakili spektrum gangguan yang terdiri dari konjungtivitis alergi perenial, keratokonjungtivitis atopik, keratokonjungtivitis vernal dan konjungtivitis papiler yang merupakan kondisi self-limiting dan dapat mempengaruhi kornea dan menyebabkan kehilangan penglihatan, baik karena penyakit itu sendiri atau karena efek samping kortikosteroid yang merupakan salah satu terapi andalan [21]. Berdasarkan dataset $40 \%$ dari populasi usia $>17$ tahun dilaporkan memiliki gejala alergi okular, dan mereka diklasifikasikan sebagai konjungtivitis alergi. Menariknya, gejala konjungtivitis alergi yang teridentifikasi dapat dipertahankan untuk subjek berusia> 50 tahun [22]. Untuk ptyergium, prevalensi yang lebih tinggi telah dilaporkan dari negara-negara dengan peningkatan garis lintang geografis dan dengan usia. Salah satu faktor risiko utama yang diidentifikasi adalah paparan sinar ultraviolet karena pekerjaan di luar ruangan. Faktor risiko lainnya adalah jenis kelamin laki-laki dan mereka yang tinggal di pedesaan [23].

Trauma kimia yang mengenai mata dapat menyebabkan kerusakan permukaan okular. Luka bakar okular yang umum adalah luka bakar kimia atau termal, dengan sebagian besar luka bakar kimia disebabkan oleh asam atau alkali. Trauma dapat mengenai konjungtiva, pembuluh darah, saraf, endotel dan keratosit dan dapat timbul ulkus pada stromal kornea, defek epitel kornea, inflamasi, gangguan lapisan air mata [24]. Pada gangguan permukaan mata yang parah seperti hilangnya sel induk epitel limbal, atau defisiensi sel induk limbal memiliki banyak komplikasi yang merusak. Defisiensi sel induk limbal adalah penyebab utama kebutaan kornea yang ditandai dengan defek epitel yang persisten, erosi dan ulserasi konjungtiva dan inflamasi kronis. Berbagai pendekatan berbasis sel induk untuk mengobati penyakit permukaan okular telah menjadi arah dan tantangan masa depan. 
Studi terbaru menunjukkan efek menguntungkan dari terapi berbasis sel induk pada penyembuhan permukaan okular, terutama menggunakan sel induk mesenchymal $[25,26]$.

\section{Ulasan Sel induk Mesenchymal}

Sel induk dewasa dibagi menjadi tiga jenis utama yaitu hematopoietik, sel progenitor spesifik jaringan, dan sel mesenchymal multipoten. Sel induk hematopoietik adalah sel induk multipoten yang menghasilkan mieloid (monosit, makrofag, neutrofil, basofil, eosinofil, sel darah merah, megakariosit dan trombosit, sel dendritik) dan sel darah limfoid (sel T dan B, sel pembunuh alami) [27]. Sel progenitor spesifik jaringan adalah sel yang berdiferensiasi buruk yang terletak di berbagai jenis jaringan dan organ dan bertanggung jawab untuk pembaruan populasi sel mereka, pada dasarnya untuk menggantikan sel-sel mati [28]. Sel-sel progenitor dapat membelah hanya beberapa kali sementara sel-sel induk lainnya mampu memperbarui diri tanpa batas [29].

Mesenchymal stem cells (MSCs) diketahui dapat berdiferensiasi menjadi berbagai jenis sel, melindungi sel dari cedera dan secara langsung dapat meningkatkan perbaikan jaringan [30]. MSCs dapat berdiferensiasi menjadi sel seperti neuron epitel, sel ganglion retina, sel glial dan fotoreseptor [31]. MSCs juga diketahui berhasil berdiferensiasi menjadi keratosit dan sel epitel kornea [32,33]. Turunan adiposa (AD) dan sumsum tulang (BM) adalah sumber MSCs yang paling umum dan tersedia. MSCs yang berasal dari adiposa dan sumsum tulang memiliki potensi yang signifikan untuk regenerasi jaringan, mereka mensekresi molekul sinyal seperti faktor neurotropik, faktor pertumbuhan atau sitokin yang dapat berdifusi dalam media jaringan lokal dan berinteraksi dengan sel terdekat [34].

MSCs dapat menimbulkan berbagai sel mesodermal seperti dijelaskan di atas, dan juga memiliki kemampuan transdiferensiasi untuk mengasumsikan fenotipe sel ektodermal saraf dan sel epitel [31]. Relatif sedikit uji klinis MSCs yang berfokus pada penyakit mata. Namun, banyak penelitian pada hewan telah didedikasikan untuk mengeksplorasi potensi terapeutik MSCs untuk mengobati retinopati, uveitis, glaukoma dan gangguan permukaan okular [35]. Studi MSCs lebih lanjut, telah menunjukkan bahwa BMMSC dapat menyerupai sel fibroblas limbal yang membantu dalam mempertahankan sel induk epitel limbal di ceruk limbal [36] yang memungkinkan bahwa MSC dapat dipandu untuk berdiferensiasi menuju sel-sel kornea. Namun demikian, in vivo ada kekurangan bukti langsung untuk mendukung diferensiasi MSC dalam mengasumsikan fenotipe sel epitel kornea. Meskipun, sel-sel yang terdiferensiasi secara in vitro dapat digunakan dalam rekayasa jaringan kornea atau pengobatan penggantian sel [33].

\section{Sumber MSCs}

MSCs pertama kali diisolasi dari sumsum tulang, meskipun ada laporan tentang sel-sel dengan kualitas serupa yang diisolasi dari sumber yang berbeda dari waktu ke waktu. 
Jaringan dan sekret orang dewasa, seperti jaringan adiposa, darah tepi, pulpa gigi, ligamen kuning, darah menstruasi, endometrium, dan ASI dari ibu, serta jaringan janin, seperti cairan ketuban, ketuban, vili korionik, plasenta, tali pusat, Jeli Wharton, dan darah tali pusat, menyediakan sel mesenchymal. Dari semua sumber tersebut, $[37,38]$. Terlepas dari kenyataan bahwa MSCs dapat diekstraksi dari berbagai jaringan pada semua fase perkembangan (janin, muda, dewasa, dan tua) ada perbedaan yang signifikan antara populasi MSCs yang diperoleh karena sifat kepatuhan plastisitinya, yaitu untuk berdiferensiasi menjadi tipe sel tertentu [39]. MSCs dapat berdiferensiasi menjadi adiposit, kondrosit, osteoblas, dan miosit, tergantung dari mana asalnya. MSCs dapat diisolasi dari sebagian besar jaringan dalam tubuh dan dikultur secara in vitro, namun tidak semuanya memiliki sifat yang sama. Misalnya, literatur yang menunjukkan sekresi MSCs dari sitokin antiinflamasi, IL-10, sangat kontradiktif, dan bisa jadi karena sumber sel mengembangkan pengobatan yang paling manjur dan hemat biaya untuk penyakit permukaan mata $[35,40,41]$.

\section{MSC yang diturunkan dari sumsum tulang (BM-MSCs)}

Sumsum tulang adalah sumber MSC yang paling banyak diselidiki dalam penelitian terapi sel OSID. BM-MSC telah menunjukkan kemanjuran untuk imunoregulasi dan perbaikan penyakit dalam beberapa model OSID in vivo dengan rute pemberian yang berbeda. Ini termasuk model hewan dari luka bakar kimia [14,42] dan mata kering yang diinduksi peradangan. Namun, batasan utama termasuk prosedur invasif dan menyakitkan untuk mengisolasi sumsum tulang, di mana hanya $0,001 \%$ hingga $0,01 \%$ dari sel akan membentuk MSC [43].

\section{MSC yang diturunkan dari adiposa (AD-MSCS)}

AD-MSCs memiliki tingkat ekspresi antigen permukaan, kemampuan diferensiasi, dan aktivitas imunosupresif yang serupa dengan BM-MSC [44]. Namun, data yang menunjukkan kemanjurannya untuk regenerasi kornea masih langka dan saling bertentangan. Penerapan AD-MSCs pada model kelinci penolakan allograft kornea meningkatkan tingkat peradangan [45]. Sebaliknya, AD-MSCs telah menunjukkan efek yang manjur pada banyak organ lain termasuk hati dan otakdicapai melalui penekanan respon imun. Sebuah studi baru-baru ini yang membandingkannya secara langsung dengan BM-MSCs menemukan pengurangan kapasitas untuk penyembuhan luka kornea secara in vitro [46].

\section{MSC yang diturunkan dari kornea (C-MSCs)}

MSC yang sudah terbiasa dengan lingkungan mikro kornea mungkin memiliki manfaat terapeutik untuk kembali ke permukaan mata setelah MSC ditransplantasikan. Telah ditunjukkan bahwa ketika diisolasi dan diperluas secara in vitro, keratosit dari stroma limbal kornea mengasumsikan fenotipe MSC $[36,47,48]$. 
Selanjutnya, C-MSC ini menunjukkan potensi anti-inflamasi ketika dikultur dengan sel epitel kornea yang terluka dapat mengurangi jaringan parut kornea setelah melukai $[49,50]$ dan mengekspresikan penanda spesifik kornea ketika tipe MSC lainnya tidak. Eksosom yang disekresikan C-MSC juga menunjukkan kapasitas untuk mempercepat penyembuhan luka epitel kornea [51,52].

\section{MSC dari sumber lain}

Pulpa gigi (DP) dan darah tali pusat (UCB) adalah sumber alternatif MSCs. DP-MSC menunjukkan karakteristik penanda dan potensi diferensiasi yang serupa dengan MSCs yang disebutkan di atas, dibandingkan dengan UCB-MSC yang menunjukkan tingkat proliferasi yang lebih tinggi, tingkat imunomodulasi yang lebih kuat, dan tingkat penuaan yang lebih rendah [44]. Meskipun penelitian terbatas menerapkan sel-sel ini pada kornea, sebuah studi ex vivo telah menunjukkan kapasitas DP-MSCs untuk meningkatkan perbaikan dan regenerasi epitel kornea manusia, DP-MSCs yang belum matang telah menunjukkan kemanjuran in vivo untuk defisiensi sel induk limbal, menyebabkan penurunan opasitas kornea dan neovaskularisasi [53] selain secara langsung dan tidak langsung menginduksi penyembuhan luka epitel kornea in vitro menyoroti potensi mereka sebagai agen terapeutik $[54,55]$.

\section{Potensi MSC pada Gangguan Permukaan Okular}

Lebih banyak pekerjaan telah dilakukan pada MSCs dan penyakit kornea [56,57]. MSCs manusia telah digunakan untuk menyembuhkan luka bakar kimia epitel kornea. MSCs turunan sumsum tulang manusia diterapkan pada kornea tikus yang dibakar secara kimia. Sel diperluas pada lembaran membran ketuban manusia yang gundul dan membran yang dirawat dengan MSCs ini dijahit ke kornea hewan pengerat tujuh hari setelah luka bakar kimia. Efek anatomi dan penglihatan hewan pengerat masingmasing diukur seminggu sekali dengan lampu celah dan dengan pelacakan kepala optokinetik. Data menunjukkan bahwa lembaran membran amnion MSCs sumsum tulang, seperti sel induk epitel limbal, berhasil merekonstruksi permukaan kornea tikus yang rusak. Menariknya, selain menutupi defek epitel, peningkatan respon penyembuhan mungkin juga berhubungan dengan penghambatan inflamasi dan angiogenesis [24].

Dalam pekerjaan yang lebih relevan dengan penyakit manusia, MSC yang diturunkan dari sumsum tulang manusia telah dikultur bersama dengan sel epitel kornea manusia yang rusak secara kimiawi melalui inkubasi dengan etanol. Hal ini mengakibatkan peningkatan kadar IL-6, VEGF, TGF- $\beta 1$, MMP-2, dan thrombospondin-1 serta penekanan sekresi MMP-9 oleh sel-sel epitel yang rusak [58]. Efek antiinflamasi dan antiangiogenik tersebut mungkin menunjukkan peran MSCs dalam menghambat penolakan cangkok kornea. MSCs tikus alogenik yang diaplikasikan secara topikal telah digunakan dalam studi jaringan kornea babi yang ditransplantasikan ke kornea tikus. Namun, ini gagal untuk memperpanjang kelangsungan hidup xenograft kornea [59]. 
Baru-baru MSC telah diaplikasikan pada terapi mata kering. Hal ini menimbulkan beberapa spekulasi bahwa MSC dapat digunakan untuk meregenerasi kelenjar lakrimal. Uji klinis Fase I/II manusia baru-baru ini mulai melihat manfaat infus intravena MSC alogenik pada peradangan kelenjar lakrimal kronis (pada sindrom Sjogren) yang telah terbukti terkait dengan peningkatan regulasi BMP7 dan diferensiasi proliferasi sel mesenchymal jaringan $[60,61]$.

Studi kornea lainnya telah berfokus pada efek antiinflamasi dan antiangiogenik MSCs. MSCs yang diturunkan dari sumsum tulang tikus telah diterapkan pada kornea tikus setelah pemberian alkohol $100 \%$ dan debridement epitel secara mekanis. Reservoir tabung berongga diaplikasikan ke kornea, diisi dengan MSC dalam media kultur dan disimpan di tempatnya selama 2 jam. Reservoir kemudian diangkat dan mata dijahit tertutup untuk menghindari debridemen fisik sel. Studi ini menunjukkan bahwa MSC mengurangi peradangan kornea dan neovaskularisasi dan ini dikaitkan dengan peningkatan ekspresi IL-10 dan TGF-beta1, IL-6, dan TSP-1 tetapi dengan penurunan ekspresi IL-2 dan IFN-y, MMP-2, dan penurunan infiltrasi sel CD4+ $[10,15]$. Menariknya, efek ini juga dapat dicapai sebagian hanya dengan menggunakan secretome dari MSC [15].

\section{MSC Secretom}

MSC mensekresi berbagai faktor autokrin/parakrin yang disebut secretome. Secretome bebas sel tampaknya dapat merekapitulasi banyak sifat/efek dalam proses regeneratif pada jaringan yang rusak, menginduksi angiogenesis, melindungi sel dari kematian sel apoptosis dan memodulasi sistem imun. MSC secretome diperkaya dalam beberapa faktor terlarut termasuk sitokin, kemokin, molekul imunomodulator, dan faktor pertumbuhan [11]. Selain itu, faktor parakrin yang diproduksi oleh sel dapat ditemukan terbungkus dalam vesikel yang disekresikan sel. Menurut ukuran dan asalnya Ekstraseluler Vesikel (EV) di dalam sel dibagi menjadi eksosom, mikrovesikel, dan badan apoptosis. Populasi vesikel berukuran nano yang lebih kecil pantas mendapat perhatian paling besar. Mikrovesikel (100-1.000 nm) berasal dari membran plasma, dan eksosom (30-120 nm) yang terbentuk dalam endosom multivesikular, memiliki rentang ukuran yang tumpang tindih dan ketika pemisahannya tidak dapat dipastikan sepenuhnya secara kolektif $[62,63]$.

Secretome memainkan peran penting dalam regulasi banyak proses fisiologis melalui mekanisme parakrin/autokrin. Setelah dilepaskan ke lingkungan ekstraseluler, secretome diambil melalui beberapa mekanisme oleh sel tetangga dan mencapai tempat yang jauh melalui cairan biologis, selanjutnya memodulasi fenotipe sel target dan sifat biologis seluler. Secretome berinteraksi dengan sel target melalui reseptor permukaan atau integrin, atau dengan menyatu dengan membran plasma (endositosis). Protein umum dalam secretome sebagian besar disekresikan dan diekspresikan selama tahap pertumbuhan spesifik, oleh tipe sel tertentu atau selama respons seluler spesifik. Oleh karena itu, mereka dapat mewakili sumber biomarker yang andal dalam cairan tubuh [64-66]. 
Secretome bekerja baik dengan mengatur ekspresi beberapa reseptor sel target termasuk tumor necrosis factor (TNF), molekul MHC Kelas I / II dan reseptor kemokin CCR5, atau dengan mentransfer senyawa bioaktif (misalnya faktor pertumbuhan, lipid dan protein) ke dalam sel target setelah fusi membran sel $[67,68]$. Ada banyak bukti dari penelitian pada hewan bahwa sejumlah besar sitokin dan faktor pertumbuhan yang bekerja bersama dalam faktor yang disekresikan MSC secretome dalam mengurangi jaringan parut, neovaskularisasi dan peradangan sambil mempromosikan epitelisasi setelah cedera kornea [69].

\section{Potensi Secretome pada Imunomodulasi Kornea}

Efek imunosupresif dan imunomodulator yang diberikan oleh MSC pertama kali dikaitkan dengan molekul yang berbeda, termasuk interferon gamma (IFN- $\gamma$ ) dan inducible nitric oxide synthase (iNOS) yang merupakan gen imunoregulator dasar yang di ekspresikan untuk membuktikan adanya regenerasi epitel kornea [70]. Kepentingan utama seputar MSC telah bergeser ke fungsi parakrin mereka, sebagai respon terapeutik positif dapat dicapai terlepas dari apakah sel mencapai organ target [71]. Ada banyak data yang menunjukkan sekresi faktor antiinflamasi, faktor mobilisasi sel, dan faktor pertumbuhan sebagai respons terhadap mediator inflamasi [11]. Stimulasi MSC dengan interferon-gamma (IFN- $\gamma$ ) telah banyak dipelajari dalam literatur, menunjukkan aktivasi IFN-y - Janus kinase (JAK) - sinyal transduser, dan aktivator transkripsi (STAT) 1 jalur yang mengarah ke sekresi indoleamine 2,3-dioxygenase (IDO), enzim katabolisme triptofan umumnya berkorelasi langsung dengan potensi imunomodulator MSCs [72,73].

Aktivasi MSC telah juga telah diselidiki dengan sitokin pro-inflamasi tumor necrosis factor- $\alpha$ (TNF- $\alpha$ ) dan interleukin (IL)-1 $\alpha /-1 \beta$, yang mengarah pada peningkatan regulasi transkripsi. faktor ription termasuk $N F k B$, dan sekresi beberapa faktor termasuk transforming growth factor- $\beta$, ciliary neurotrophic factor, glial cell line-derived neurotrophic factor, interleukins- $1 \beta,-6,-8$, and -10 , nitric oxide (NO), faktor pertumbuhan hepatosit (HGF), dan faktor pertumbuhan endotel vaskular (VEGF). Beberapa aktivitas parakrin MSC-secretome dalam berbagai model penyakit permukaan okular dapat dilihat pada tabel 1 [74].

Tabel 1 Aktivitas parakrin MSC-secretome dalam berbagai model penyakit permukaan ocular

\begin{tabular}{|c|c|c|c|c|}
\hline Sumber MSC & Faktor Bioaktif & Model Hewan & Hasil Penelitian & Referensi \\
\hline $\begin{array}{l}\text { UCMSCS } \\
\text { manusia }\end{array}$ & VEGF & $\begin{array}{l}\text { Luka bakar alkali } \\
\text { kornea kelinci }\end{array}$ & $\begin{array}{l}\text { Mata yang diobati dengan } \\
\text { MSC menunjukkan } \\
\text { pemulihan yang lebih baik. } \\
\text { Rata-ratararea } \\
\text { neovaskularisasi secara } \\
\text { signifikan lebih kecil }\end{array}$ & \\
\hline
\end{tabular}




\begin{tabular}{|c|c|c|c|}
\hline $\begin{array}{l}\text { BMMSCs dan } \\
\text { AD-MSCs } \\
\text { kelinci }\end{array}$ & $\begin{array}{l}\text { TGF- } \beta 1 \text { dan } \\
\text { VEGF }\end{array}$ & $\begin{array}{l}\text { Luka bakar alkali } \\
\text { kornea kelinci }\end{array}$ & $\begin{array}{l}\text { MSC mengurangi [42] } \\
\text { neovaskularisasi, kekeruhan } \\
\text { kornea, dan tingkat VEGF } \\
\text { dan } \alpha \text {-SMA kornea. Mereka } \\
\text { jugar menghasilkan } \\
\text { peningkatan re-epitelisasi } \\
\text { dan proliferasi keratosit. }\end{array}$ \\
\hline $\begin{array}{l}\text { BMMSCs } \\
\text { mencit }\end{array}$ & TSG-6 & $\begin{array}{l}\text { Model tikus } \\
\text { diabetes dari cedera } \\
\text { epitel kornea }\end{array}$ & $\begin{array}{l}\text { Transplantasi MSC lokal [76] } \\
\text { dengan sekresi TSG-6 secara } \\
\text { signifikan mempercepat } \\
\text { penyembuhan luka, } \\
\text { meningkatkan proliferasi sel } \\
\text { induk epitel, dan } \\
\text { pengurangan } \\
\text { inflamasi infiltrat }\end{array}$ \\
\hline $\begin{array}{l}\text { CMSCs } \\
\text { manusia dan } \\
\text { mencit }\end{array}$ & PEDF & $\begin{array}{l}\text { Vaskularisasi kornea } \\
\text { tikus }\end{array}$ & $\begin{array}{l}\text { Penghambatan } \\
\text { neovaskularisasi kornea, } \\
\text { kemungkinan melalui sFLT-1 } \\
\text { dan PEDF yang disekresikan }\end{array}$ \\
\hline $\begin{array}{l}\text { ADMSCs } \\
\text { manusia }\end{array}$ & TSG-6 & $\begin{array}{l}\text { Luka bakar alkali } \\
\text { akut yang parah } \\
\text { pada kelinci }\end{array}$ & $\begin{array}{l}\text { MSCs mengurangi cacat [77] } \\
\text { epitel, menurunkan respon } \\
\text { inflamasi dan fibroblastik, } \\
\text { dan menghindari pencairan } \\
\text { kornea dan symblepharon. }\end{array}$ \\
\hline $\begin{array}{l}\text { ADMSCs } \\
\text { manusia }\end{array}$ & $\begin{array}{l}\text { IL-10, TGF- } \beta \text {, } \\
\text { dan TSG-6 }\end{array}$ & $\begin{array}{l}\text { LSCD parsial dan } \\
\text { total kelinci }\end{array}$ & $\begin{array}{l}\text { MSC mengurangi [78] } \\
\text { peradangan, menghambat } \\
\text { neovaskularisasi } \\
\text { kekeruhan kornea karena } \\
\text { keterlibatan beberapa } \\
\text { molekul anti-inflamasi }\end{array}$ \\
\hline BMMSCs kelinci & $\begin{array}{l}\text { IDO-2, HGF, } \\
\text { TGF-b, dan } \\
\text { VEGF }\end{array}$ & $\begin{array}{l}\text { Luka bakar alkali } \\
\text { kornea kelinci }\end{array}$ & $\begin{array}{l}\text { Temuan mengungkapkan [79] } \\
\text { bahwa BM-MSC memiliki } \\
\text { efek terapeutik pada } \\
\text { pemulihan permukaan mata } \\
\text { yang rusak yang sebanding } \\
\text { dengan LSC spesifik jaringan. }\end{array}$ \\
\hline
\end{tabular}




\begin{tabular}{|c|c|c|c|}
\hline ADMSCs kelinci & $\begin{array}{l}\text { IFN- } \gamma \text { dan TNF- } \\
\alpha\end{array}$ & $\begin{array}{l}\text { Model penolakan } \\
\text { allograft kornea } \\
\text { risiko tinggi kelinci }\end{array}$ & $\begin{array}{l}\text { AD-MSCs tidak menjadi [45] } \\
\text { rumah bagi kornea atau } \\
\text { engraft, } \\
\text { meningkatkan peradangan } \\
\text { dan neovaskularisasi, } \\
\text { kurangnya remampuan } \\
\text { imunosupresif, r dan } \\
\text { karakterisasi molekul sekresi } \\
\text { imunofenotipikal }\end{array}$ \\
\hline BM-MSCs tikus & TGF- $\beta$ & $\begin{array}{l}\text { Luka bakar alkali } \\
\text { kornea tikus }\end{array}$ & $\begin{array}{l}\text { MSC mempromosikan } \\
\text { pemulihan epitel, kejernihan } \\
\text { kornea, mengurangi } \\
\text { neovaskularisasi, } \quad \text { dan } \\
\text { mengurangi MIP-1a dan } \\
\text { MCP-1. }\end{array}$ \\
\hline $\begin{array}{l}\text { BMMSCs } \\
\text { manusia }\end{array}$ & $\begin{array}{l}\text { IL-1 } \beta \text { dan TNF- } \\
\alpha\end{array}$ & GVHD tikus & $\begin{array}{l}\text { MSC mencegah infiltrasi [81] } \\
\text { limfosit T dan mengurangi } \\
\text { penanda gen inflamasi TNF, } \\
\text { PAX6, dan Sprr1b dan } \\
\text { mengurangi keratinisasi } \\
\text { kornea }\end{array}$ \\
\hline $\begin{array}{l}\text { BMMSCs } \\
\text { mencit }\end{array}$ & $\begin{array}{l}\text { TGF- } \beta \text {, dan } \\
\text { TSG-6 }\end{array}$ & $\begin{array}{l}\text { Cedera mekanis } \\
\text { kornea tikus }\end{array}$ & $\begin{array}{l}\text { MSC menyebabkan [82] } \\
\text { peningkatan kadar HGF } \\
\text { pada permukaan mata, yang } \\
\text { membantu mengembalikan } \\
\text { transparansi kornea dan } \\
\text { menekan ekspresi } \alpha-S M A \\
\text { yang diinduksi TGF-B }\end{array}$ \\
\hline $\begin{array}{l}\text { BMMSCs } \\
\text { mencit }\end{array}$ & $\mathrm{HGF}$ & $\begin{array}{l}\text { Model transplantasi } \\
\text { kornea tikus }\end{array}$ & $\begin{array}{l}\text { MSCs menghambat infiltrasi [83] } \\
\text { leukosit kornea, } \\
\text { pematangan APC dan } \\
\text { generasi sel Th1 untuk } \\
\text { meningkatkan kelangsungan } \\
\text { hidup cangkok. Data } \\
\text { menunjukkan HGF sebagai } \\
\text { faktor parakrin utama }\end{array}$ \\
\hline $\begin{array}{l}\text { Rat MSC. } \\
\text { Sumber tidak } \\
\text { diketahui }\end{array}$ & $\begin{array}{l}\text { TGF- } \beta 1, \text { IL-10, } \\
\text { IL-6 }\end{array}$ & $\begin{array}{l}\text { Luka bakar kimia } \\
\text { kornea tikus }\end{array}$ & $\begin{array}{l}\text { Potensi anti-inflamasi MSC [15] } \\
\text { melalui IL-6 yang menekan } \\
\text { pematangan DC, dan anti } \\
\text { angiogenik } \quad \text { melalui } \\
\text { peningkatan regulasi TSP-1 }\end{array}$ \\
\hline
\end{tabular}




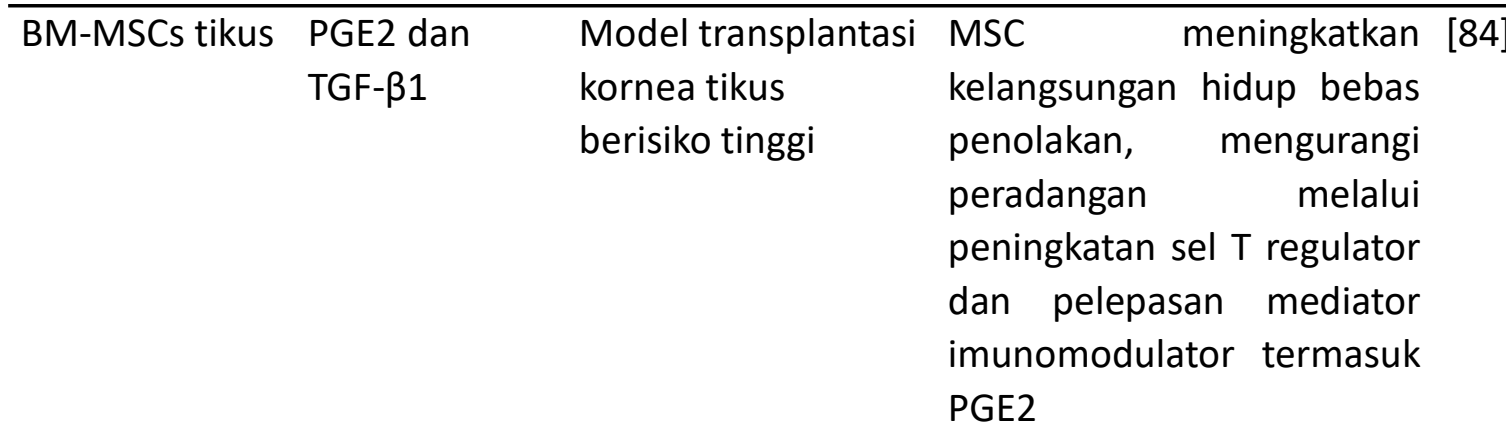

\begin{tabular}{llll}
\hline BMMSCs & TGF- $\beta$ dan IL- & Model transplantasi & MSC ditempatkan langsung \\
mencit & 1Ra & ke permea tikus & meradang, menghambat \\
& & pematangan APC, menekan \\
& allosensitization, dan \\
& meningkatkan \\
& kelangsungan \\
& allograft
\end{tabular}

\begin{tabular}{lll}
\hline BMMSCs & IL-1 $\beta$ dan TNF- & Cedera mekanis \\
mencit & $\alpha$ & MSC yang diberikan melalui \\
& kornea tikus & subseks intravena dan \\
& signifikan mengurangi \\
& peradangan, opasitas \\
& kornea, fibrosis, dan \\
& mengembalikan integritas \\
& epitel dan arsitektur \\
& jaringan
\end{tabular}

\begin{tabular}{|c|c|c|c|}
\hline $\begin{array}{l}\text { BMMSCs } \\
\text { manusia }\end{array}$ & TSG-6 & $\begin{array}{l}\text { Neovaskularisasi } \\
\text { kornea yang } \\
\text { diinduksi jahitan } \\
\text { tikus }\end{array}$ & 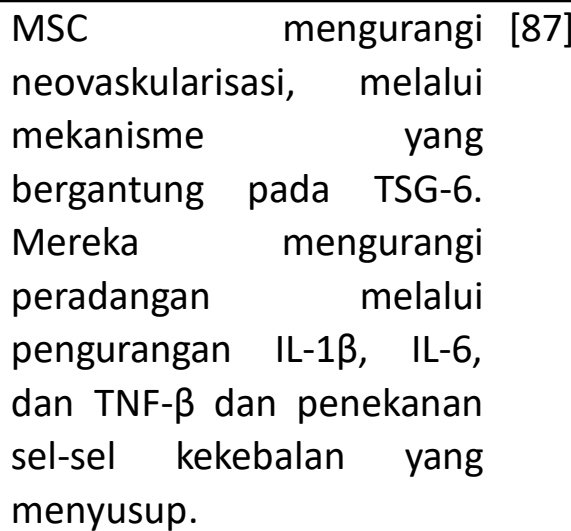 \\
\hline
\end{tabular}

\begin{tabular}{llll}
\hline BMMSCs & IFN- $y$ and & Cedera mekanis & MSC secara signifikan [88] \\
mencit & iNOS & kornea tikus & mengurangi respons imun, \\
& & melalui penekanan \\
& & ekspresi gen IFN-y, iNOS, \\
& dan IL-2 dalam sel kornea \\
& lokal \\
\hline
\end{tabular}




\section{Keterangan}

BMMSCs (Bone marrow mesenchymal stem cells); ADMSCs (Adipose mesenchymal stem cells); CMSCs (corneal mesenchymal stem cells); UCMSCs (umbilical cord mesenchymal stem cells); VEGF (vascular endothelial growth factor); TGF- $\beta 1$ (transforming growth factor- $\beta 1$ ); TSG-6 (TNF-a-stimulated gene/protein 6); PEDF (pigment epithelial derived factor); IL-2,6,10 (interleukin-2,6,10); LSCD (limbal stem cell deficiency); sFLT-1 (soluble fms-like tyrosine kinase-1); IDO-2 (indoleamine-2,3dioxygenase); HGF (hepatocyte growth factor); TNF-a (Tumor Necrosis Factor alpha); GVHD (graft versus host disease); MMP9 (matrixmetalloproteinase 9); iNOS (inducible nitric oxide synthase); a -SMA ( $\alpha$-smooth muscle actin); APCs (antigen presenting cells); PGE2 (prostaglandin-E2): anti- angiogenic cytokine (TSP-1); chemo- taxis (MIP$1 \alpha$ and MCP-1).

Menggunakan pensinyalan parakrin, MSC pada akhirnya dapat menekan aktivasi dan fungsi berbagai sel dalam sistem imun adaptif dan bawaan, termasuk limfosit $\mathrm{T}$ dan $\mathrm{B}$, makrofag, sel pembunuh alami, neutrofil, dan sel dendritik. Beberapa studi permukaan kornea dan mata telah menunjukkan pengurangan faktor inflamasi setelah pemberian MSC in vitro dan in vivo $[49,85]$, selain kapasitasnya untuk menghambat penyakit yang didorong oleh alergi, seperti konjungtivitis alergi, melalui mekanisme antialergi yang bergantung pada COX-2 [89].

Pertimbangan awal mengenai penggunaan MSC untuk OSD adalah hubungan antara faktor pertumbuhan yang disekresikan dan angiogenesis. Pada jaringan jantung iskemik, MSC mempromosikan neovaskularisasi melalui upregulasi VEGF [90]. Angiogenesis okular adalah faktor utama penyakit mata yang membutakan termasuk penyakit retina, seperti gangguan makula terkait usia, dirangsang oleh peningkatan VEGF [91]. Sebaliknya, MSC telah menunjukkan efek sebaliknya pada neovaskularisasi ketika diterapkan pada cedera kornea yang disebabkan oleh luka bakar kimia dimana satu studi menunjukkan penurunan regulasi VEGF dan pengurangan signifikan neovaskularisasi pada kornea yang diobati dengan MSC [14]. Hal ini dapat di kaitkan dengan peningkatan regulasi trombospondin-1 yang diinduksi MSC, penghambat VEGF dan menandakan pentingnya lingkungan mikro pada perilaku MSC [15].

Faktor pertumbuhan hepatosit (HGF) juga telah terlibat sebagai faktor fundamental dalam imunomodulasi, yang disekresikan oleh MSC yang distimulasi dengan IL-1ß [83]. HGF saja cukup kuat untuk menekan aktivasi sel penyaji antigen dan untuk membatasi pembentukan sel Th1 dalam jaringan limfoid. Aplikasi HGF topikal secara signifikan mengurangi penolakan cangkok kornea dalam model murine GVHD melalui penekanan infiltrasi sel imun, dan memiliki potensi untuk mempertahankan dan mengembalikan transparansi kornea melalui penghambatan a -SMA ( $\alpha$-smooth muscle actin) dan penginduksinya TGF-ß $[82,85]$. 
Molekul anti-angiogenik kunci lainnya yang disekresikan oleh MSC termasuk gen/protein terstimulasi TNF-a (TSG-6), ditunjukkan sebagai vital dalam penghambatan neovaskularisasi, dan disarankan untuk berfungsi melalui penghambatan infiltrasi makrofag dan induksi apoptosis sel endotel vaskular [87].

Seperti halnya makrofag, TSG-6 telah ditunjukkan untuk menekan aktivasi dan infiltrasi neutrofil setelah cedera kornea kimia dan mekanik [16], menjadikannya modulator kuat dari angiogenesis dan inflamasi. Metode alternatif untuk mengeksploitasi mekanisme pensinyalan parakrin MSC ini untuk mengobati OSD adalah melalui pengambilan vesikel ekstraseluler dari MSC untuk aplikasi terapeutik [92]. Faktor terapeutik kuat MSC yang dikemas dalam vesikel kecil dapat membantu mengatasi rintangan keamanan dan regulasi aplikasi sel dan telah menunjukkan potensi dalam penyembuhan luka kornea dan imunomodulasi in vivo [51]. Jalur dan interaksi berbagai MSC dan lingkungan mikro kornea sebelumnya diketahui dapat membantu meningkatkan profil keamanan dan nilai terapeutik sel-sel untuk regenerasi jaringan dan penekanan inflamasi, yang selanjutnya dengan menyoroti kebutuhan untuk mengeksplorasi sumber MSC yang berbeda.

\section{Prospektif Penulis}

Penggunaan MSCs telah berkembang pesat dalam kedokteran oftalmologi. Sebuah studi pada tikus dan manusia menunjukkan mekanisme di mana MSCs menampilkan aktivitas yang menguntungkan dalam memfasilitasi fungsi sel epitel kornea yang tersisa dengan memulihkan ceruk sel induk limbal yang sudah ada sebelumnya di kornea atau mereka mungkin berdiferensiasi menjadi keratosit (fibroblas kornea) untuk mendukung lingkungan yang menguntungkan bagi pemulihan ceruk sel induk limbal. Namun diferensiasi MSCs menjadi keratosit tidak dapat diperiksa, karena keratosit tidak memiliki penanda spesifiknya dan memiliki banyak penanda yang sama dengan MSCs [15], sangat mungkin bahwa MSCs akan bertindak melalui mekanisme parakrin sel dan sitokin yang lebih kompleks selain IL-10, TGF-beta, dan TSP -1 yang menjadikannya hanya bagian dari keseluruhan mekanisme imunomodulator. Menariknya dalam pengamatan, aktivitas MSC secretome dalam mekanisme sel untuk berbagai model penyakit permukaan okular terlihat sama. Penggunaan MSC secretome diketahui dapat meningkatkan mobilisasi sel induk mesenchymal. Pendekatan untuk meningkatkan terapi menggunakan MSC secretome di masa depan dapat dicapai dengan memahami kaskade dan mekanisme yang mendasari proses regenerasi jaringan terutama pada aplikasi gangguan permukaan okular. Selain itu MSC secretome telah diusulkan untuk meningkatkan terapi non-seluler seperti memanfaatkan obat-obatan konvensional, mengevaluasi kedekatan pengiriman ke tempat pengobatan, dan mengatasi penolakan, sehingga menghindari kesulitan transplantasi sel tradisional. 


\section{Kesimpulan}

Inflamasi memainkan peran kunci dalam patogenesis penyakit yang telah diamati pada gangguan permukaan okular. Efek anti inflamasi dan penyembuhan luka dari MSC Secretome baru-baru ini telah dibuktikan secara in vitro dan in vivo dalam model eksperimental penyakit permukaan mata seperti luka epitel kornea, serta diketahui memiliki efek regeneratif sesuai dengan karakteristik lokasi cedera. Secretome dapat mengurangi inflamasi kornea dan neovaskularisasi melalui peningkatan ekspresi IL-10, TGF- $\beta 1$, IL-6, TNF- $\alpha$ (TSG-6)dan TSP-1 yang berperan penting sebagai imunosupresif serta mengurangi sekresi sitokin inflamasi. Keuntungan dari aplikasi MSC secretome meliputi: kemampuan untuk mengirimkan populasi sel yang terkonsentrasi ke area yang kecil, tanpa bergantung pada mekanisme homing sel; pengiriman segera molekul pensinyalan parakrin ke area target memungkinkan penyembuhan yang lebih cepat; dan pengiriman berpotensi menghindari penolakan alogenik. Meskipun banyak keuntungan saat melakukan terapi menggunakan MSC secretome, jenis dan sumber sel induk serta teknik kultur sel perlu dipertimbangkan. Selain itu MSC secretome tampaknya layak dan menarik untuk dilakukan penelitian lebih lanjut terkait dengan regulasi imunnomodulasi aplikasi topikal MSC secretome terutama untuk gangguan permukaan okular.

\section{Daftar Pustaka}

1. Amano S, Yamagami S, Mimura T, Uchida S, Yokoo S. Corneal Stromal and Endothelial Cell Precursors, Cornea. 2006;25:S73-S77. Available from: https://doi.org/10.1097/01.ico.0000247218.10672.7e.

2. Dartt DA, Willcox MDP. Complexity of the tear film: Importance in homeostasis and dysfunction during disease, Exp. Eye Res. 2013;117:1-3. Available from: https://doi.org/10.1016/j.exer.2013.10.008.

3. Stern ME, Schaumburg CS, Dana R, Calonge M, Niederkorn JY, Pflugfelder SC. Autoimmunity at the okular surface: Pathogenesis and regulation, Mucosal Immunololgy. 2010;3:425-442. Available from: https://doi.org/10.1038/mi.2010.26.

4. Surgery M, Hospital S, Surgery M, Key S, Processing F, Park G-Y, et al. Tissue Engineering and Regenerative Medicine. Concise Review : Cell-Based Strategies in Bone Tissue Engineering and Regenerative Medicine, Stem Cells Transl. Med. 2014;4:1-10.

5. Li F. Mesenchymal stem cells: Potential role in corneal wound repair and transplantation, World J. Stem Cells. 2014;6:296. Available from: https://doi.org/10.4252/wjsc.v6.i3.296.

6. Reinshagen $\mathrm{H}$, Auw-Haedrich $\mathrm{C}$, Sorg RV, Boehringer $\mathrm{D}$, Eberwein $\mathrm{P}$, Schwartzkopff $\mathrm{J}$, et al. Corneal surface reconstruction using adult mesenchymal stem cells in experimental limbal stem cell deficiency in rabbits, Acta Ophthalmol. 2011;89:741-748. Available from: https://doi.org/10.1111/j.17553768.2009.01812.x. 
7. Cejkova J, Trosan P, Cejka C, Lencova A, Zajicova A, Javorkova E, et al. Suppression of alkali-induced oxidative injury in the cornea by mesenchymal stem cells growing on nanofiber scaffolds and transferred onto the damaged corneal surface, Exp. Eye Res. 2013;116:312-323. Available from: https://doi.org/10.1016/j.exer.2013.10.002.

8. Holan V, Javorkova E. Mesenchymal Stem Cells, Nanofiber Scaffolds and Okular Surface Reconstruction, Stem Cell Rev. Reports. 2013;9:609-619. Available from: https://doi.org/10.1007/s12015-013-9449-0.

9. Jiang TS, Cai L, Ji WY, Hui YN, Wang YS, Hu D, et al. Reconstruction of the corneal epithelium with induced marrow mesenchymal stem cells in rats, Mol. Vis. 2010;16:1304-1316.

10. Eslani M, Putra I, Shen X, Hamouie J, Tadepalli A, Anwar KN, et al. CorneaDerived Mesenchymal Stromal Cells Therapeutically Modulate Macrophage Immunophenotype and Angiogenic Function, Stem Cells. 2018;36:775-784. Available from: https://doi.org/10.1002/stem.2781.

11. Madrigal M, Rao KS, Riordan NH. A review of therapeutic effects of mesenchymal stem cell secretions and induction of secretory modification by different culture methods 2014:1-14.

12. Eslani M, Putra I, Shen X, Hamouie J, Afsharkhamseh N, Besharat S, et al. Corneal mesenchymal stromal cells are directly antiangiogenic via PEDF and sFLT-1, Investig. Ophthalmol. Vis. Sci. 2017;58:5507-5517. Available from: https://doi.org/10.1167/iovs.17-22680.

13. Yazdanpanah G, Haq Z, Kang K, Jabbehdari S, Rosenblatt MI, Djalilian AR. Strategies for reconstructing the limbal stem cell niche, Ocul. Surf. 2019;17:230240. Available from: https://doi.org/10.1016/j.jtos.2019.01.002.

14. Yao L, rong-Li Z, ru Su W, ping Li Y, li Lin M, xin Zhang W, et al. Role of mesenchymal stem cells on cornea wound healing induced by acute alkali burn, PLoS One. 2012;7. Available from: https://doi.org/10.1371/journal.pone.0030842.

15. Oh JY, Kim MK, Shin MS, Lee HJ, Ko JH, Wee WR, et al. The Anti-Inflammatory and Anti-Angiogenic Role of Mesenchymal Stem Cells in Corneal Wound Healing Following Chemical Injury, Stem Cells. 2008;26:1047-1055. Available from: https://doi.org/10.1634/stemcells.2007-0737.

16. Oh JY, Roddy GW, Choi H, Lee RH, Ylöstalo JH, Rosa $\mathrm{RH}$, et al. Antiinflammatory protein TSG-6 reduces inflammatory damage to the cornea following chemical and mechanical injury, Proc. Natl. Acad. Sci. U. S. A. 2010;107:16875-16880. https://doi.org/10.1073/pnas.1012451107. Available from:

17. Vizoso FJ, Eiro N, Cid S, Schneider J, Perez-Fernandez R. Mesenchymal stem cell secretome: Toward cell-free therapeutic strategies in regenerative medicine, Int. J. Mol. Sci. 2017;18. Available from: https://doi.org/10.3390/ijms18091852.

18. Gayton JL. Etiology, prevalence, and treatment of dry eye disease, Clin. Ophthalmol. 2009;3:405-412. Available from: https://doi.org/10.2147/opth.s5555.

19. Tan G, Li J, Song Y, Yu Y, Liu D, Pan W. Phenylboronic acid-tethered chondroitin sulfate-based mucoadhesive nanostructured lipid carriers for the treatment of dry eye syndrome, Acta Biomater. 20199;9:350-362. Available from: https://doi.org/10.1016/j.actbio.2019.08.035. 
20. Schaumberg DA, Sullivan DA, Dana MR. Epidemiology of dry eye syndrome, Adv. Exp. Med. Biol. 2002;506 B:989-998. Available from: https://doi.org/10.1007/978-1-4615-0717-8_140.

21. Pisella PJ, Brignole F, Debbasch C, Lozato PA, Creuzot-Garcher C, Bara J, et al. Flow cytometric analysis of conjunctival epithelium in okular rosacea and keratoconjunctivitis sicca, Ophthalmology. 2000;107:1841-1849. Available from: https://doi.org/10.1016/S0161-6420(00)00347-X.

22. Miyazaki D, Fukagawa K, Okamoto S, Fukushima A, Uchio E, Ebihara N, et al. Epidemiological aspects of allergic conjunctivitis, Allergol. Int. 2020;69:487-495. Available from: https://doi.org/10.1016/j.alit.2020.06.004.

23. Liu L, Wu J, Geng J, Yuan Z, Huang D. Geographical prevalence and risk factors for pterygium: A systematic review and meta-analysis, BMJ Open. 2013;3. Available from: https://doi.org/10.1136/bmjopen-2013-003787.

24. Ma Y, Xu Y, Xiao Z, Yang W, Zhang C, Song E, et al. Reconstruction of Chemically Burned Rat Corneal Surface by Bone Marrow-Derived Human Mesenchymal Stem Cells, Stem Cells. 2006; 24:315-321. Available from: https://doi.org/10.1634/stemcells.2005-0046.

25. He H, Yiu SC. Stem cell-based therapy for treating limbal stem cells deficiency: A review of different strategies, Saudi J. Ophthalmol. 2014;28:188-194. Available from: https://doi.org/10.1016/j.sjopt.2014.06.003.

26. Haagdorens M, Van Acker SI, Van Gerwen V, Ní Dhubhghaill S, Koppen C, Tassignon MJ, et al. Limbal stem cell deficiency: Current treatment options and emerging therapies, Stem Cells Int. 2016;2016. Available from: https://doi.org/10.1155/2016/9798374.

27. Eaves CJ. Hematopoietic stem cells: Concepts, definitions, and the new reality, Blood. 2015; 125:2605-2613. Available from: https://doi.org/10.1182/blood-201412-570200.

28. Le T, Chong J. Cardiac progenitor cells for heart repair, Cell Death Discov. 2016;21-4. Available from: https://doi.org/10.1038/cddiscovery.2016.52.

29. Klimczak A, Kozlowska U. Mesenchymal stromal cells and tissue-specific progenitor cells: Their role in tissue homeostasis, Stem Cells Int. 2016;2016. Available from: https://doi.org/10.1155/2016/4285215.

30. Beyazyildiz E, Pinarli FA, Beyazyildiz Ö, Hekimollu ER, Acar U, Demir M, et al. Efficacy of topical mesenchymal stem cell therapy in the treatment of experimental dry eye syndrome model, Stem Cells Int. 2014; 2014. Available from: https://doi.org/10.1155/2014/250230.

31. Phinney DG, Prockop D., Concise Review: Mesenchymal Stem/Multipotent Stromal Cells: The State of Transdifferentiation and Modes of Tissue RepairCurrent Views, Stem Cells. 2007;25:2896-2902. Available from: https://doi.org/10.1634/stemcells.2007-0637.

32. Sun J, Liu WH, Deng FM, Luo YH, Wen K, Zhang H, et al. Differentiation of rat adipose-derived mesenchymal stem cells into corneal-like epithelial cells driven by PAX6, Exp. Ther. Med. 2018;15:1424-1432. Available from: https://doi.org/10.3892/etm.2017.5576.

33. Zhang L, Coulson-Thomas VJ, Ferreira TG, Kao WWY. Mesenchymal stem cells for treating okular surface diseases, BMC Ophthalmol. 2015;15. Available from: https://doi.org/10.1186/s12886-015-0138-4. 
34. Lin N, Hu K, Chen S, Xie S, Tang Z, Lin J, et al. Nerve growth factor-mediated paracrine regulation of hepatic stellate cells by multipotent mesenchymal stromal cells, Life Sci. 2009;85:291-295. Available from: https://doi.org/10.1016/j.lfs.2009.06.007.

35. Joe AW, Gregory-Evans K. Mesenchymal stem cells and potential applications in treating okular disease, Curr. Eye Res. 2010;35:941-952. Available from: https://doi.org/10.3109/02713683.2010.516466.

36. Polisetty N, Fatima A, Madhira SL, Sangwan VS, Vemuganti GK. Mesenchymal cells from limbal stroma of human eye, Mol. Vis. 2008;14:431-442.

37. Gan L, Liu Y, Cui D, Pan Y, Zheng L, Wan M. Dental Tissue-Derived Human Mesenchymal Stem Cells and Their Potential in Therapeutic Application, Stem Cells Int. 2020;2020. Available from: https://doi.org/10.1155/2020/8864572.

38. Muhammad SA, Abbas AY, Saidu Y, Fakurazi S, Bilbis LS. Therapeutic efficacy of mesenchymal stromal cells and secretome in pulmonary arterial hypertension: a systematic review and meta-analysis, Biochimie. 2019. Available from: https://doi.org/10.1016/j.biochi.2019.10.016.

39. Miao Z, Jin J, Chen L, Zhu J, Huang W, Zhao J, et al. Isolation of mesenchymal stem cells from human placenta: Comparison with human bone marrow mesenchymal stem cells, Cell Biol. Int. 2006;30:681-687. Available from: https://doi.org/10.1016/j.cellbi.2006.03.009.

40. Crisan M, Yap S, Casteilla L, Chen CW, Corselli M, Park TS, et al. A Perivascular Origin for Mesenchymal Stem Cells in Multiple Human Organs, Cell Stem Cell. 2008;3:301-313. Available from: https://doi.org/10.1016/j.stem.2008.07.003.

41. Sabapathy V, Kumar S. hiPSC-derived iMSCs: NextGen MSCs as an advanced therapeutically active cell resource for regenerative medicine, J. Cell. Mol. Med. 2016;20:1571-1588. Available from: https://doi.org/10.1111/jcmm.12839.

42. Cejka C, Holan V, Trosan P, Zajicova A, Javorkova E, Cejkova J. The Favorable Effect of Mesenchymal Stem Cell Treatment on the Antioxidant Protective Mechanism in the Corneal Epithelium and Renewal of Corneal Optical Properties Changed after Alkali Burns, Oxid. Med. Cell. Longev. 2016;2016. Available from: https://doi.org/10.1155/2016/5843809.

43. Lee MJ, Ko AY, Ko JH, Lee HJ, Kim MK, Wee WR, et al. Accepted manuscript 2014. Available from: https://doi.org/10.1038/mt.2014.159.

44. Jin HJ, Bae YK, Kim M, Kwon SJ, Jeon HB, Choi SJ, et al. Comparative analysis of human mesenchymal stem cells from bone marrow, adipose tissue, and umbilical cord blood as sources of cell therapy, Int. J. Mol. Sci. 2013;14:1798618001. Available from: https://doi.org/10.3390/iims140917986.

45. Fuentes-Julián S, Arnalich-Montiel F, Jaumandreu L, Leal M, Casado A, GarcíaTuñon I, et al. Adipose-derived mesenchymal stem cell administration does not improve corneal graft survival outcome, PLoS One. 2015;10:1-25. Available from: https://doi.org/10.1371/journal.pone.0117945.

46. Nieto-Nicolau N, Martín-Antonio B, Müller-Sánchez C, Casaroli-Marano RP. In vitro potential of human mesenchymal stem cells for corneal epithelial regeneration, Regen. Med. 2020;15:1409-1426. Available from: https://doi.org/10.2217/rme-2019-0067. 
47. Sidney LE, Hopkinson A. Corneal keratocyte transition to mesenchymal stem cell phenotype and reversal using serum-free medium supplemented with fibroblast growth factor-2, transforming growth factor- $\beta 3$ and retinoic acid, J. Tissue Eng. Regen. Med. 2018;12:e203-e215. Available from: https://doi.org/10.1002/term.2316.

48. Branch MJ, Hashmani K, Dhillon P, Jones DRE, Dua HS, Hopkinson A. Mesenchymal stem cells in the human corneal limbal stroma, Investig. Ophthalmol. Vis. Sci. 2012;53:5109-5116. Available from: https://doi.org/10.1167/iovs.11-8673.

49. Orozco Morales ML, Marsit NM, McIntosh OD, Hopkinson A, Sidney LE. Antiinflammatory potential of human corneal stroma-derived stem cells determined by a novel in vitro corneal epithelial injury model, World J. Stem Cells. 2019;11:84-99. Available from: https://doi.org/10.4252/wjsc.v11.i2.84.

50. Hertsenberg AJ, Shojaati G, Funderburgh ML, Mann MM, Du Y, Funderburgh JL. Corneal stromal stem cells reduce corneal scarring by mediating neutrophil infiltration after wounding, PLoS One. 2017;12:1-16. Available from: https://doi.org/10.1371/journal.pone.0171712.

51. Samaeekia R, Rabiee B, Putra I, Shen X, Park YJ, Hematti P, et al. Effect of human corneal mesenchymal stromal cell-derived exosomes on corneal epithelial wound healing, Investig. Ophthalmol. Vis. Sci. 2018;59:5194-5200. Available from: https://doi.org/10.1167/iovs.18-24803.

52. Hashmani K, Branch MJ, Sidney LE, Dhillon PS, Verma M, McIntosh OD, et al. Characterization of corneal stromal stem cells with the potential for epithelial transdifferentiation, Stem Cell Res. Ther. 2013;4. Available from: https://doi.org/10.1186/scrt226.

53. Gomes JÁP, Monteiro BG, Melo GB, Smith RL, da Silva MCP, Lizier NF, et al. Corneal reconstruction with tissue-engineered cell sheets composed of human immature dental pulp stem cells, Investig. Ophthalmol. Vis. Sci. 2010;51:14081414. Available from: https://doi.org/10.1167/iovs.09-4029.

54. Joyce NC, Harris DL, Markov V, Zhang Z, Saitta B. Potential of human umbilical cord blood mesenchymal stem cells to heal damaged corneal endothelium, Mol. Vis. 2012;18:547-564.

55. Azmi SM, Salih M, Abdelrazeg S, Roslan FF, Mohamed R, Jie TJ, et al. Human umbilical cord-mesenchymal stem cells: A promising strategy for corneal epithelial regeneration, Regen. Med. 2020;15:1381-1397. Available from: https://doi.org/10.2217/rme-2019-0103.

56. Ambrose W, Schein O, Elisseeff J. A Tale of Two Tissues: Stem Cells in Cartilage and Corneal Tissue Engineering, Curr. Stem Cell Res. Ther. 2010;5:37-48. Available from: https://doi.org/10.2174/157488810790442804.

57. Robertson DM, Alexander LJ, Bonanno JA, Fleiszig SMJ, McNamara N. Cornea and Okular Surface Disease, Optom. Vis. Sci. 2014;91:S3-S16. Available from: https://doi.org/10.1097/opx.0000000000000226.

58. Oh JY, Kim MK, Shin MS, Wee WR, Lee JH. Cytokine secretion by human mesenchymal stem cells cocultured with damaged corneal epithelial cells, Cytokine. 2009;46:100-103. https://doi.org/10.1016/j.cyto.2008.12.011.

Available from: 
59. Oh JY, Kim MK, Ko JH, Lee HJ, Lee JH, Wee WR. Rat allogeneic mesenchymal stem cells did not prolong the survival of corneal xenograft in a pig-to-rat model, Vet. Ophthalmol. 2009;12:35-40. Available from: https://doi.org/10.1111/j.14635224.2009.00724.x.

60. Zoukhri D. Mechanisms involved in injury and repair of the murine lacrimal gland: Role of programmed cell death and mesenchymal stem cells, Ocul. Surf. 2010;8:60-69. Available from: https://doi.org/10.1016/S1542-0124(12)70070-8.

61. Zoukhri D, Fix A, Alroy J, Kublin CL. Mechanisms of murine lacrimal gland repair after experimentally induced inflammation, Investig. Ophthalmol. Vis. Sci. 2008;49:4399-4406. Available from: https://doi.org/10.1167/iovs.08-1730.

62. Lötvall J, Hill AF, Hochberg F, Buzás El, Di Vizio D, Gardiner C, et al. Minimal experimental requirements for definition of extracellular vesicles and their functions: A position statement from the International Society for Extracellular Vesicles, J. Extracell. Vesicles. 2014;3. Available from: https://doi.org/10.3402/jev.v3.26913.

63. Raposo G, Stoorvogel W. Extracellular vesicles: Exosomes, microvesicles, and friends, J. Cell Biol. 2013;200:373-383. Available from: https://doi.org/10.1083/jcb.201211138.

64. Parolini I, Federici C, Raggi C, Lugini L, Palleschi S, De Milito A, et al. Microenvironmental $\mathrm{pH}$ is a key factor for exosome traffic in tumor cells, J. Biol. Chem. 2009;284:34211-34222. Available from: https://doi.org/10.1074/jbc.M109.041152.

65. Turturici G, Tinnirello R, Sconzo G, Geraci F. Extracellular membrane vesicles as a mechanism of cell-to-cell communication: Advantages and disadvantages, Am. J. Physiol. - Cell Physiol. 2014;306. Available from: https://doi.org/10.1152/ajpcell.00228.2013.

66. Marote A, Teixeira FG, Mendes-Pinheiro B, Salgado AJ. MSCs-derived exosomes: Cell-secreted nanovesicles with regenerative potential, Front. Pharmacol. 2016;7:1-8. Available from: https://doi.org/10.3389/fphar.2016.00231.

67. Schaffer. Engineering microenvironments to control stem cell fate and function, StemBook. 2008:1-12. Available from: https://doi.org/10.3824/stembook.1.5.1.

68. Gnecchi M, Zhang Z, Ni A, Dzau VJ. Paracrine mechanisms in adult stem cell signaling and therapy, Circ. Res. 2008;103:1204-1219. Available from: https://doi.org/10.1161/CIRCRESAHA.108.176826.

69. Fernandes-Cunha GM, Na KS, Putra I, Lee HJ, Hull S, Cheng YC, et al. Corneal Wound Healing Effects of Mesenchymal Stem Cell Secretome Delivered Within a Viscoelastic Gel Carrier, Stem Cells Transl. Med. 2019;8:478-489. Available from: https://doi.org/10.1002/sctm.18-0178.

70. Rostami Z, Khorashadizadeh M, Naseri M. Immunoregulatory properties of mesenchymal stem cells: Micro-RNAs, Immunol. Lett. 2020;219:34-45. Available from: https://doi.org/10.1016/j.imlet.2019.12.011.

71. Fischer UM, Harting MT, Jimenez F, Monzon-Posadas WO, Xue H, Savitz SI, et al. Pulmonary passage is a major obstacle for intravenous stem cell delivery: The pulmonary first-pass effect, Stem Cells Dev. 2009;18:683-691. Available from: https://doi.org/10.1089/scd.2008.0253. 
72. Kim DS, Jang IK, Lee MW, Ko YJ, Lee DH, Lee JW, et al. Enhanced Immunosuppressive Properties of Human Mesenchymal Stem Cells Primed by Interferon-y, EBioMedicine. 2018;28:261-273. Available from: https://doi.org/10.1016/j.ebiom.2018.01.002.

73. Krampera M, Galipeau J, Shi Y, Tarte K, Sensebe L. Immunological characterization of multipotent mesenchymal stromal cells-The international society for cellular therapy (ISCT) working proposal, Cytotherapy. 2013;15:10541061. Available from: https://doi.org/10.1016/j.jcyt.2013.02.010.

74. Kean TJ, Lin P, Caplan AI, Dennis JE. MSCs: Delivery routes and engraftment, cell-targeting strategies, and immune modulation, Stem Cells Int. 2013;2013. Available from: https://doi.org/10.1155/2013/732742.

75. Almaliotis D, Koliakos G, Papakonstantinou E, Komnenou A, Thomas A, Petrakis $S$, et al. Mesenchymal stem cells improve healing of the cornea after alkali injury, Graefe's Arch. Clin. Exp. Ophthalmol. 2015;253:1121-1135. Available from: https://doi.org/10.1007/s00417-015-3042-y.

76. Di G, Du X, Qi X, Zhao X, Duan H, Li S, et al. Mesenchymal stem cells promote diabetic corneal epithelial wound healing through TSG-6-dependent stem cell activation and macrophage switch, Investig. Ophthalmol. Vis. Sci. 2017;58:40644074. Available from: https://doi.org/10.1167/iovs.17-21506.

77. Espandar L, Caldwell D, Watson R, Blanco-Mezquita T, Zhang S, Bunnell B. Application of adipose-derived stem cells on scleral contact lens carrier in an animal model of severe acute alkaline burn, Eye Contact Lens. 2014;40:243247. Available from: https://doi.org/10.1097/ICL.0000000000000045.

78. Galindo S, Herreras JM, López-Paniagua M, Rey E, de la Mata A, Plata-Cordero $\mathrm{M}$, et al. Therapeutic Effect of Human Adipose Tissue-Derived Mesenchymal Stem Cells in Experimental Corneal Failure Due to Limbal Stem Cell Niche Damage, Stem Cells. 2017;35:2160-2174. Available from: https://doi.org/10.1002/stem.2672.

79. Petrenko Y, Vackova I, Kekulova K, Chudickova M, Koci Z, Turnovcova K, et al. A Comparative Analysis of Multipotent Mesenchymal Stromal Cells derived from Different Sources, with a Focus on Neuroregenerative Potential, Sci. Rep. 2020;10:1-15. Available from: https://doi.org/10.1038/s41598-020-61167-z.

80. Ke Y, Wu Y, Cui X, Liu X, Yu M, Yang C, et al. Polysaccharide hydrogel combined with mesenchymal stem cells promotes the healing of corneal alkali burn in rats, PLoS One. 2015;10:1-18. Available from: https://doi.org/10.1371/journal.pone.0119725.

81. Martínez-Carrasco R, Sánchez-Abarca LI, Nieto-Gómez C, Martín García E, Sánchez-Guijo $F$, Argüeso $P$, et al. Subconjunctival injection of mesenchymal stromal cells protects the cornea in an experimental model of GVHD, Ocul. Surf. 2019;17:285-294. Available from: https://doi.org/10.1016/j.jtos.2019.01.001.

82. Mittal SK, Omoto M, Amouzegar A, Sahu A, Rezazadeh A, Katikireddy KR, et al. Restoration of Corneal Transparency by Mesenchymal Stem Cells, Stem Cell Reports. 2016;7:583-590. Available from: https://doi.org/10.1016/j.stemcr.2016.09.001. 
83. Mittal SK, Foulsham W, Shukla S, Elbasiony E, Omoto M, Chauhan SK. Mesenchymal Stromal Cells Modulate Corneal Alloimmunity via Secretion of Hepatocyte Growth Factor, Stem Cells Transl. Med. 2019;8:1030-1040. Available from: https://doi.org/10.1002/sctm.19-0004.

84. Lohan P, Murphy N, Treacy O, Lynch K, Morcos M, Chen B, et al. Third-party allogeneic mesenchymal stromal cells prevent rejection in a pre-sensitized highrisk model of corneal transplantation, Front. Immunol. 2018;9:1-14. Available from: https://doi.org/10.3389/fimmu.2018.02666.

85. Dicicco RM, Bell BA, Kaul C, Hollyfield JG, Anand-apte B, Perkins BD, et al. C.C. Foundation, IOVS Papers in Press. Published on September 9, 2014 as Manuscript iovs.14-14724,2014;01:1-41.

86. Shukla S, Mittal SK, Foulsham W, Elbasiony E, Singhania D, Sahu SK, et al. Therapeutic efficacy of different routes of mesenchymal stem cell administration in corneal injury, Ocul. Surf. 2019;17:729-736. Available from: https://doi.org/10.1016/j.jtos.2019.07.005.

87. Song HB, Park SY, Ko JH, Park JW, Yoon CH, Kim DH, et al. Mesenchymal Stromal Cells Inhibit Inflammatory Lymphangiogenesis in the Cornea by Suppressing Macrophage in a TSG-6-Dependent Manner, Mol. Ther. 2018;26:162-172. Available from: https://doi.org/10.1016/j.ymthe.2017.09.026.

88. Zajicova A, Pokorna K, Lencova A, Krulova M, Svobodova E, Kubinova S, et al. Treatment of okular surface injuries by limbal and mesenchymal stem cells growing on nanofiber scaffolds, Cell Transplant. 2010;19:1281-1290. Available from: https://doi.org/10.3727/096368910X509040.

89. Su W, Wan Q, Huang J, Han L, Chen X, Chen G, et al. Culture medium from TNF-a-stimulated mesenchymal stem cells attenuates allergic conjunctivitis through multiple antiallergic mechanisms, J. Allergy Clin. Immunol. 2015;136:423-432.e8. Available from: https://doi.org/10.1016/j.jaci.2014.12.1926.

90. Lee EY, Xia Y, Kim WS, Kim MH, Kim TH, Kim KJ, et al. Hypoxia-enhanced wound-healing function of adipose-derived stem cells: Increase in stem cell proliferation and up-regulation of VEGF and bFGF, Wound Repair Regen. 2009;17:540-547. Available from: https://doi.org/10.1111/j.1524475X.2009.00499.x.

91. Sulaiman RS, Basavarajappa HD, Corson TW. Natural product inhibitors of okular angiogenesis, Exp. Eye Res. 2014;129:161-171. Available from: https://doi.org/10.1016/j.exer.2014.10.002.

92. Gomzikova MO, James V, Rizvanov AA. Therapeutic Application of Mesenchymal Stem Cells Derived Extracellular Vesicles for Immunomodulation, Front. Immunol. 2019;10:1-9. Available from: https://doi.org/10.3389/fimmu.2019.02663. 